\title{
Lipoprotein lipase gene-deficient mice with hypertriglyceridaemia associated with acute pancreatitis $^{1}$
}

\author{
Maochun Tang ${ }^{\mathrm{I}}$, Pengfei Zong, Ting Zhang ${ }^{\mathrm{I}}$, Dongyan Wang ${ }^{\mathrm{I}}$, Yuhui Wang ${ }^{\mathrm{II}}$, Yan Zhao ${ }^{\mathrm{I}}$ \\ DOI: http://dx.doi.org/10.1590/S0102-865020160100000003 \\ IMD, Department of Gastroenterology, Shanghai Tenth People's Hospital, Tongji University School of Medicine, Shanghai, China. Conception and \\ design of the study, analysis of data, manuscript writing, final approved.

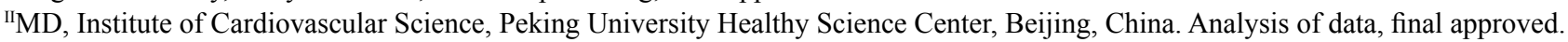

\begin{abstract}
PURPOSE: To investigate the severity of pancreatitis in lipoprotein lipase (LPL)-deficient hypertriglyceridaemic (HTG) heterozygous mice and to establish an experimental animal model for HTG pancreatitis study.

METHODS: LPL-deficient HTG heterozygous mice were rescued by somatic gene transfer and mated with wild-type mice. The plasma amylase, triglyceride, and pathologic changes in the pancreas of the LPL-deficient HTG heterozygous mice were compared with those of wild-type mice to assess the severity of pancreatitis. In addition, acute pancreatitis (AP) was induced by caerulein (50 $\mu \mathrm{g} / \mathrm{kg}$ ) for further assessment.

RESULTS: The levels of plasma amylase and triglyceride were significantly higher in the LPL-deficient HTG heterozygous mice. According to the pancreatic histopathologic scores, the LPL-deficient HTG heterozygous mice showed more severe pathologic damage than the wild-type mice.

CONCLUSIONS: Lipoprotein lipase deficient heterozygous mice developed severe caerulein-induced pancreatitis. In addition, their high triglyceride levels were stable. Therefore, LPL-deficient HTG heterozygous mice are a useful experimental model for studying HTG pancreatitis.
\end{abstract}

Key words: Hypertriglyceridemia. Pancreatitis. Lipoprotein Lipase. Mice. 


\section{Introduction}

Hyperlipidaemic acute pancreatitis (HLAP), also known as hypertriglyceridaemic pancreatitis (HTGP), is a severe or even fatal complication of hypertriglyceridaemia (HTG). Studies have shown that HTG accounts for about $1 \%$ to $13 \%$ of all pancreatitis cases $^{1}$ and $20 \%$ of non-alcoholic and non-biliary pancreatitis cases ${ }^{2}$. HTG has become the most common cause of pancreatitis, aside from biliary and alcoholic pancreatitis ${ }^{1,3,4}$. HLAP has a high mortality rate, a high recurrence rate and has many complications ${ }^{5,6}$. However, the pathogenesis of pancreatitis caused by hypertriglyceridaemia is still unknown. Thus, establishing reasonable animal models for studying HLAP is essential. Hyperlipidaemic animal models mainly include congenital, transgenic and chemically induced types $^{7}$, wherein rats and mice are more extensively used. Related technologies are also more mature and practical, but they also have their respective limitations ${ }^{8,9}$. Rats and mice are poorly sensitive to diet and their synthesis and clearance rates for plasma lipoprotein are quite different from those of humans, which leads to uneven blood lipid levels in the models and other shortcomings, aside from their protracted feeding times. Therefore, using rats and mice as ideal hyperlipidaemic models is difficult. Although guinea pigs, hamsters, and gerbils are relatively less used in experiments, their lipid metabolisms are more similar to that of humans, which should be given sufficient attention ${ }^{10}$. The high-fat diet and the high-fat emulsion gavage method are the most commonly used modelling methods. High-fat animal models established by feeding can be divided into exogenous type and endogenous type. Exogenous high-fat models are mainly established through direct feeding with feed containing high cholesterol, lard, egg yolk powder, and so on. High-fat diet methods are in line with the pathogenesis of human hyperlipidaemia caused by diet and are used extensively. However, the modelling time is relatively long. In addition, indicator uniformity of the model animals is poor because of individual differences. The high-fat emulsion gavage method ensures the uniformity of individual high-fat emulsion intakes, thereby compensating for the shortcomings of the feeding method. However, this method severely irritates animals, and long-term stress can affect the experimental results. Transgenic modelling has a higher cost and requires relatively complex technology. However, the uniformity and stability of transgenic animal models are better and heritable. Thus, this method has been widely used in scientific researches ${ }^{11}$. Congenital animal models (i.e., spontaneous hyperlipidemia animal models) have stable symptoms and are heritable. These models have different degrees of similarity with the formation mechanism of human hyperlipidemia, and thus highly applicable. However, the difficulty of sourcing and their high costs restrict their experimental application. In conclusion, with the development of animal modelling technology, transgenic models have increasingly important role because of their similarity with human diseases. In this research, we used transgenic animals with good uniformity and stability (i.e., LPL-deficient heterozygous mice). These animals were intraperitoneally injected with caerulein to prepare an HLAP mouse model. The effect of this new experimental model on hyperlipidaemic pancreatitis was discussed.

\section{Methods}

The animal use protocol has been reviewed and approved by the Institutional Animal Care and Use Committee (IACUC) of Medicine of Peking University. A total of 26 4-month-old LPL-deficient heterozygous C57BL6 mice supplied by the Cardiovascular Institute of Department of Medicine of Peking University, were selected for this experiment. Twenty-eight female wild-type C57BL6 mice were treated as the control group. This study was carried out in strict accordance with the recommendations in the Guide for the Care and Use of Laboratory Animals of the National Institutes of Health. The test groups are shown in Table 1.

TABLE 1 - Animal test groups.

\begin{tabular}{|c|c|}
\hline $\begin{array}{c}\text { Normal blood lipid } \\
\text { group (wild type) }(\mathrm{n}=28)\end{array}$ & $\begin{array}{r}\text { Hyperlipidemia group } \\
\text { (heterozygote) }(\mathrm{n}=26)\end{array}$ \\
\hline $\begin{array}{l}\text { E: control group of wild } \\
\text { type with normal saline } \\
\quad \text { for } 12 \mathrm{~h}(\mathrm{n}=7)\end{array}$ & $\begin{array}{c}\text { A: control group of heterozygote } \\
\text { animals with normal saline for } 12 \\
\qquad \mathrm{~h}(\mathrm{n}=6)\end{array}$ \\
\hline $\begin{array}{l}\text { F: control group of wild } \\
\text { type with normal saline } \\
\text { for } 24 \mathrm{~h}(\mathrm{n}=7)\end{array}$ & $\begin{array}{l}\text { B: control group of heterozygote } \\
\text { animals with normal saline for } 24 \\
\qquad h(n=6)\end{array}$ \\
\hline $\begin{array}{l}\text { G: experimental group of } \\
\text { wild type animals with } \\
\text { intraperitoneal } \\
\text { administration of caerulin } \\
\text { for } 12 \mathrm{~h}(\mathrm{n}=7)\end{array}$ & $\begin{array}{l}\text { C: experimental group of } \\
\text { heterozygote animals with } \\
\text { intraperitoneal administration of } \\
\text { caerulin for } 12 \mathrm{~h}(\mathrm{n}=7)\end{array}$ \\
\hline $\begin{array}{l}\text { H: experimental group of } \\
\text { wild type animals with } \\
\text { intraperitoneal } \\
\text { administration of caerulin } \\
\text { for } 24 \mathrm{~h}(\mathrm{n}=7)\end{array}$ & $\begin{array}{l}\text { D: experimental group of } \\
\text { heterozygote animals with } \\
\text { intraperitoneal administration of } \\
\text { caerulin for } 24 \mathrm{~h}(\mathrm{n}=7)\end{array}$ \\
\hline
\end{tabular}

The test animals were fasted, but water was given $(>12 \mathrm{~h})$. The animals in the experimental group, i.e., LPL-deficient heterozygote mice (hyperlipidaemia group), were intraperitoneally injected seven times with caerulein at $50 \mu \mathrm{g} / \mathrm{kg}$. For the control 
group, normal saline was used instead of caerulein. The remaining treatments were similar to that in as the experimental group. Once the models were established, blood was collected at $12 \mathrm{~h}$ and $24 \mathrm{~h}$ after the first caerulein administration. The mice were then killed and pancreatic tissue specimens were reserved and fixed in $10 \%$ formaldehyde solution for HE staining.

\section{Blood lipid and amylase}

The laboratory animals were fasted for $12 \mathrm{~h}$, but with access to water. Orbital venous blood was collected and heparin was used for anticoagulation. The blood samples were centrifuged at $4000 \mathrm{r} / \mathrm{min}$ for $10 \mathrm{~min}$ at $4^{\circ} \mathrm{C}$. Plasma was obtained and stored at $-20^{\circ} \mathrm{C}$ for detection. Commercial kits (Beijing Biosino Biotechnology Co., Ltd.) were used determine plasma TG and amylase. To determine the TG concentration and amylase activity, $490 \mathrm{~nm}$ and $405 \mathrm{~nm}$ absorbance of the reaction products was detected, respectively, in accordance with the kit instructions and the data were calculated (MODEL550 microplate reader, BioRad).

\section{Histological analysis}

When the laboratory animals were killed, pancreatic tissues were immediately obtained and fixed in $10 \%$ formaldehyde solution. Afterward, the tissues were dehydrated, embedded, sectioned and stained with HE. One person observed the sections. Pancreatic tissue was classified as semiquantitative integral based on the criteria by Schmidt et al. ${ }^{12}$, namely, oedema, inflammatory cell infiltration, parenchymal haemorrhage, parenchymal necrosis, vacuolization and other indicators. Double blind scoring was used.

\section{Statistics analysis}

The experimental data are expressed as mean \pm standard deviation. Analysis was carried out using SPSS 20.0. Data between groups were analysed with a t-test and differences with $\mathrm{p}<0.05$ were considered statistically significant.

\section{Results}

\section{Plasma TG and amylase levels}

The TG of each LPL-deficient heterozygous mouse increased stably and was $3.58 \mathrm{mmol} / \mathrm{L} \pm 0.03 \mathrm{mmol} / \mathrm{L}$. The difference was significant compared with the wild-type $(0.91 \mathrm{mmol} / \mathrm{L} \pm 0.02 \mathrm{mmol} / \mathrm{L})$. Compared with the wild-type control group, the increase in amylase level in the LPL-defective heterozygous mice in the experimental group was statistically significant (Table 2).

TABLE 2 - TG and amylase levels of wild type and heterozygote group.

\begin{tabular}{ccccccccc}
\hline & \multicolumn{3}{c}{ Heterozygote } & & \multicolumn{3}{c}{ Wild type } \\
& $\begin{array}{c}\text { Control } \\
\text { group 12 h }\end{array}$ & $\begin{array}{c}\text { Control } \\
\text { group 24 h }\end{array}$ & $\begin{array}{c}\text { Experimental } \\
\text { group 12 h }\end{array}$ & $\begin{array}{c}\text { Experimental } \\
\text { group 24 h }\end{array}$ & $\begin{array}{c}\text { Control } \\
\text { group 12 h }\end{array}$ & $\begin{array}{c}\text { Control } \\
\text { group 24 h }\end{array}$ & $\begin{array}{c}\text { Experimental } \\
\text { group 12 h }\end{array}$ & $\begin{array}{c}\text { Experimental } \\
\text { group 24 h }\end{array}$ \\
\hline Amylase & $471.29 \pm$ & $549.98 \pm$ & $3685.06 \pm$ & $3019.81 \pm$ & $358.33 \pm$ & $385.76 \pm$ & $2500.89 \pm$ & $2090.67 \pm$ \\
$(\mathrm{U} / \mathrm{L})$ & 22.74 & 93.49 & $483.98^{*} \#$ & $643.36^{*} \#$ & 42.72 & 37.49 & $409.59^{*}$ & $700.95^{*}$ \\
TG & $3.547 \pm$ & $3.55 \pm$ & $3.548 \pm$ & $3.557 \pm$ & $0.937 \pm$ & $0.884 \pm$ & $0.92 \pm$ & $0.921 \pm$ \\
$(\mathrm{Mmol} / \mathrm{L})$ & 0.27 & 0.27 & 0.267 & 0.321 & 0.183 & 0.149 & 0.107 & 0.074 \\
\hline
\end{tabular}

*Compared with wild type control group, $\mathrm{p}<0.05$

\#Compared with wild type experimental group, $\mathrm{p}<0.05$.

\section{Pancreatic histopathologic examination}

The pancreatic lobules of the wild-type mice were arranged in line and have an integral structure under light microscopy (Figure 1 D-F). Vascular degeneration was observed in some LPL-deficient heterozygous mice cells. Under light microscopy, oedema was clearly observed in the pancreatic mesenchyme of the heterozygote experimental group at each time point. The leaf interval, interlobular septa and acinar interval were widened. Point-focal necrosis of the acinar cells was observed, especially after $12 \mathrm{~h}$. Granulocyte infiltration was observed in the interval cells, and bleeding was not serious (Figure $1 \mathrm{~A}-\mathrm{C}$ ). The pancreatic histopathologic scores are shown in Table 3. 


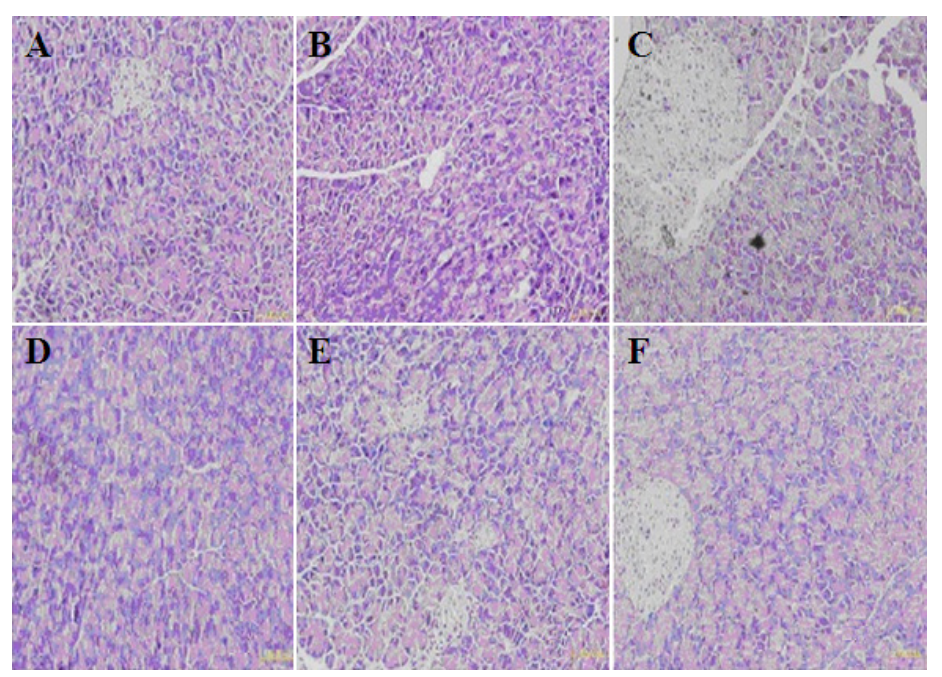

FIGURE 1 - Representative images of histological changes in pancreatic tissue, $12 \mathrm{~h}, 24 \mathrm{~h}$ after injection of caerulein. Tissue samples were stained with haematoxylin-eosin and observed at magnifications, x200 as indicated. Top panel (A, B and C): LPL deficient HTG heterozygous mice; bottom panel (D, $\mathbf{E}$ and $\mathbf{F})$ : wild type mice.(A: heterozygote control group $\times 200$, B: heterozygote experimental group $12 \mathrm{~h} \times 200$, C: heterozygote experimental group $24 \mathrm{~h} \times 200$, D: wild type control group $\times 200$, E: wild type experimental group $12 \mathrm{~h} \times 200, \mathbf{F}$ : wild type experimental group $24 \mathrm{~h}$ $\times 200)$.

TABLE 3 - Pancreatic histological semi-quantitative integral.

\begin{tabular}{|c|c|c|c|c|c|}
\hline Test groups & $\begin{array}{l}\text { Time } \\
\text { point }\end{array}$ & Edema & Necrosis & Bleeding & $\begin{array}{l}\text { Inflamma- } \\
\text { tory cell } \\
\text { infiltration }\end{array}$ \\
\hline \multirow{4}{*}{$\begin{array}{l}\text { Heterozy- } \\
\text { gote control } \\
\text { group }\end{array}$} & $12 \mathrm{~h}$ & $0.80 \pm$ & $1.78 \pm$ & $0.80 \pm$ & $0.10 \pm$ \\
\hline & & 0.27 & 0.43 & 0.25 & 0.22 \\
\hline & $24 \mathrm{~h}$ & $0.80 \pm$ & $1.77 \pm$ & $0.81 \pm$ & $0.10 \pm$ \\
\hline & & 0.26 & $0.42 *$ & 0.23 & 0.22 \\
\hline \multirow{4}{*}{$\begin{array}{l}\text { Heterozy- } \\
\text { gote ex- } \\
\text { perimental } \\
\text { group }\end{array}$} & $12 \mathrm{~h}$ & $3.94 \pm$ & $3.94 \pm$ & $1.84 \pm$ & $1.84 \pm$ \\
\hline & & $0.21^{*}$ & $0.21 *$ & $0.25 *$ & $0.25^{*}$ \\
\hline & $24 \mathrm{~h}$ & $3.57 \pm$ & $2.05 \pm$ & $1.13 \pm$ & $1.18 \pm$ \\
\hline & & $0.37^{*}$ & 0.87 & 0.52 & $0.66^{*}$ \\
\hline \multirow{4}{*}{$\begin{array}{l}\text { Wild type } \\
\text { control } \\
\text { group }\end{array}$} & $12 \mathrm{~h}$ & $0.50 \pm$ & $0.50 \pm$ & $0.50 \pm$ & $0.10 \pm$ \\
\hline & & 0.50 & 0.35 & 0.50 & 0.22 \\
\hline & $24 \mathrm{~h}$ & $0.50 \pm$ & $0.50 \pm$ & $0.50 \pm$ & $0.10 \pm$ \\
\hline & & 0.50 & 0.35 & 0.50 & 0.22 \\
\hline \multirow{4}{*}{$\begin{array}{l}\text { Wild type } \\
\text { experimen- } \\
\text { tal group }\end{array}$} & $12 \mathrm{~h}$ & $3.06 \pm$ & $2.52 \pm$ & $0.46 \pm$ & $0.58 \pm$ \\
\hline & & 0.01 & 0.51 & 0.22 & 0.38 \\
\hline & $24 \mathrm{~h}$ & $2.52 \pm$ & $1.41 \pm$ & $0.58 \pm$ & $0.27 \pm$ \\
\hline & & 0.01 & 0.22 & 0.44 & 0.22 \\
\hline
\end{tabular}

*Compared with wild type experimental group, $\mathrm{p}<0.05$.

\section{Discussion}

Hyperlipidaemia, also known as abnormal lipid metabolism, is an important cause of fatty liver, atherosclerosis, and other diseases. Recently, hypertriglyceridaemia has become a cause of acute pancreatitis. Among numerous animal models, transgenic animals exhibit various diseases through genes nonexpression or overexpression. Thus, the expression of the diseases tends to be more stable. Proteins involved in lipid metabolism mainly include three categories, corresponding receptors, apolipoprotein (Apo) and lipid metabolism-related enzymes and transport proteins ${ }^{13}$. LPL belongs to the lipase superfamily and is a key enzyme in lipid metabolism. LPL dysfunction may induce hyperlipidaemia and metabolic disorders, including highTG hyperlipidaemia and low-HDL hyperlipidaemia ${ }^{14-16}$, which is in accordance with the clinical characteristics of HLAP, i.e., high-TG hyperlipidaemia. Clinical studies have confirmed that the incidence of pancreatitis is 360 times higher among patients with severe hypertriglyceridaemia with $5 \%$ lower LPL activity ${ }^{17}$. LPL gene defects may lead to the occurrence of severe HTGP ${ }^{18}$. Chang et al. ${ }^{19}$ analysed the LPL gene of 134 patients with HLAP by denaturing high-performance liquid chromatography and highresolution melting analysis and found that the frequency of LPL mutations among HTGP patients was significantly higher than that of the normal controls.

Consequently, LPL genetically altered mice are potentially ideal animal models for HLAP research. Ross et al. ${ }^{20}$, the Institute of Cardiovascular Research of Peking University, and their Canadian collaborators have successfully established the LPL gene knockout C57BL6 mice together. The mice were male homozygous LPL (-/-) gene knockout on a C57BL/6 background. Due to the lack of LPL, CM and VLDL accumulation occurred after nursing, and the mice die within $48 \mathrm{~h}$ after birth. Therefore, LPL (-/-) newborn mice must be treated through somatic gene transfer of LPL447 within 12h after birth. Upon reaching adulthood, the mice exhibit extremely high triglycerides levels and spontaneous pancreatitis, which is in line with human LPL defects. In this experiment, heterozygous mice, obtained by mating the treated mice with wild-type C57BL6 mice, were used. The mice were characterized with stable moderate hyperlipidaemia, which provides a stable animal disease model for studying acute pancreatitis associated with hyperlipidemia.

In this study, the histopathologic scores and haematuria amylase changes indicated that LPL-deficient mice showed more severe acute pancreatitis than wild-type mice when induced with the same dose of bombesin. To determine whether the HTG mice 
were easily induced to develop pancreatitis, their pancreatitis susceptibility was studied through the AP model established via the intraperitoneal injection of caerulein. The caerulein-induced by acute pancreatitis model is widely used ${ }^{21}$ and is advantageous for evaluating the morphologic and biochemical changes in experimental rodents. Thus, we induced acute pancreatitis using intraperitoneal caerulein injections in these transgenic animals. Caerulein directly stimulates pancreas cells, which activated trypsinogen in pancreatic acinar cells and caused cell damage and necrosis ${ }^{21}$. Histologic observations of hyperlipidaemic acute pancreatitis in the heterozygote experimental group showed that pancreatitis changes in LPL-deficient heterozygote mice were clearly more serious than in the wild-type mice, as well as oedema and inflammatory cell infiltration were more obvious. The difference in amylase activity between the two groups was significant, which indicates that the LPL-deficient heterozygote mice were more susceptible to pancreatitis or their disease was easier to aggravate under the influence of the same pathogenic factors. Similar studies ${ }^{21-25}$ also show that the HTG induced by high-cholesterol diets, triglyceride infusion or the injection of an active detergent (Triton WR 1339) intensifies the course of pancreatitis. These findings support that both of endogenous and exogenous HTG increases susceptibility to acute pancreatitis.

\section{Conclusions}

Lipoprotein lipase-deficient heterozygous mice were used to simulate human moderate hypertriglyceridaemic and provide experimental evidence that HTG aggravates pancreatitis. Therefore, this model is an ideal animal model for HTG pancreatitis.

\section{References}

1. Shetty S, Xing C, Garg A. Type 1 Hyperlipoproteinemia due to Compound Heterozygous Rare Variants in GCKR. J Clin Endocrinol Metab. 2016 [Epub ahead of print].

2. Singh HK, Prasad MS, Kandasamy AK, Dharanipragada K. Tamoxifen-induced hypertriglyceridemia causing acute pancreatitis. J Pharmacol Pharmacother. 2016;7(1):38-40. doi: 10.4103/0976500X.179365.

3. Wang HL, Yu KJ. Sequential blood purification therapy for critical patients with hyperlipidemic severe acute pancreatitis. World J Gastroenterol. 2015;21(20):6304-9. doi: 10.3748/wjg.v21.i20.6304.

4. Capurso G, Archibugi L, Stigliano S, Delle Fave G. Epidemiology, clinical features and treatment of chronic pancreatitis: current knowledge and future perspectives. Recenti Prog Med. 2016;107:328-36. doi: 10.1701/2296.24696.

5. Rajendran R, Abu E, Fadl A, Byrne CD. Late effects of childhood cancer treatment: severe hypertriglyceridaemia, central obesity, non alcoholic fatty liver disease and diabetes as complications of childhood total body irradiation. Diabet Med. 2013;30:e239-42. doi: 10.1111/dme.12234.

6. Tsuang W, Navaneethan U, Ruiz L, Palascak JB, Gelrud A. Hypertriglyceridemic pancreatitis: presentation and management. Am J Gastroenterol. 2009;104:984-91. doi: 10.1038/ajg.2009.27.

7. Zaragoza C, Gomez-Guerrero C, Martin-Ventura JL, BlancoColio L, Lavin B, Mallavia B, Tarin C, Mas S, Ortiz A, Egido J. Animal models of cardiovascular diseases. J Biomed Biotechnol. 2011;2011:497841. doi: 10.1155/2011/497841.

8. Ooi EM, Barrett PH, Watts GF. The extended abnormalities in lipoprotein metabolism in familial hypercholesterolemia: developing a new framework for future therapies. Int $\mathrm{J}$ Cardiol. 2013;168(3):1811-8. doi: 10.1016/j.ijcard.2013.06.069.

9. Ahmadsei M, Lievens D, Weber C, von Hundelshausen P, Gerdes $\mathrm{N}$. Immune-mediated and lipid-mediated platelet function in atherosclerosis. Curr Opin Lipidol. 2015;26(5):438-48. doi: 10.1097/MOL.0000000000000212.

10. Hu G, Zhao Y, Tang Y, Wang Y, Shen J, Liu L, Li H, Liu Y, Cui X, Yu Y, Guo C, Wang X, Liu G. Development of a novel model of hypertriglyceridemic acute pancreatitis in hamsters: protective effects of probucol. Pancreas. 2012;41(6):845-8. doi: 10.1097/ MPA.0b013e318247d784.

11. Wang Y, Sternfeld L, Yang F, Rodriguez JA, Ross C, Hayden MR, Carriere F, Liu G, Hofer W, Schulz I. Enhanced susceptibility to pancreatitis in severe hypertriglyceridaemic lipoprotein lipasedeficient mice and agonist-like function of pancreatic lipase in pancreatic cells. Gut. 2009;58(3):422-30. doi: 10.1136/ gut.2007.146258.

12. Schmidt J, Lewandrowsi K, Warshaw AL, Compton CC, Rattner DW. Morphometric characteristics and homogeneity of a new model of acute pancreatitis in the rat. Int J Pancreatol. 1992;12:41-51. PMID: 1527449

13. Lever SZ. Targeting molecular imaging. In: Welch MJ, Eckelman WC (eds). Florida: CRC Press, Taylor \& Francis Group; 2012.

14. Sacks FM. The crucial roles of apolipoproteins E and C-III in apoB lipoprotein metabolism in normolipidemia and hypertriglyceridemia. Curr Opin Lipidol. 2015;26(1):56-63. doi: 10.1097/MOL.0000000000000146.

15. Radhakutty A, Shen J, Hooper AJ, Miller SA, Burnett JR, Mah PM, Burt MG, Doogue MP. Quantification and genotyping of lipoprotein lipase in patients with diabetic lipaemia. Diabet Med. 2014;31(12):1702-7. doi: 10.1111/dme.12565.

16. Sun K, Yang W, Huang Y, Wang Y, Xiang L, Qi J. Leu452His mutation in lipoprotein lipase gene transfer associated with hypertriglyceridemia in mice in vivo. PLoS One. 2013;8(9):e75462. doi: 10.1371/journal.pone.0075462.

17. Sisman G, Erzin Y, Hatemi I, Caglar E, Boga S, Singh V, Senturk H. Familial chylomicronemia syndrome related chronic pancreatitis: a single-center study. Hepatobiliary Pancreat Dis Int. 2014;13(2):20914. PMID: 24686550.

18. Bartha I, Dinya T, Seres I, Paragh G, Ross C, Hayden MR, Biró S, Vargha G. Acute hypertriglyceridemic pancreatitis during pregnancy due to homozygous lipoprotein lipase gene mutation. Clin Chim Acta. 2009;400(1-2):137-8. doi: 10.1016/j.cca.2008.10.016.

19. Chang YT, Chang MC, Su TC, Liang PC, Su YN, Kuo CH, Wei SC, Wong JM. Lipoprotein lipase mutation S447X associated with pancreatic calcification and steatorrhea in hyperlipidemic pancreatitis. J Clin Gastroenterol. 2009;43(6):591-6. doi: 10.1097/ MCG.0b013e3181734a30.

20. Ross CJ, Liu G, Kuivenhoven JA, Twisk J, Rip J, van Dop W, Excoffon KJ, Lewis SM, Kastelein JJ, Hayden MR. Complete rescue of lipoprotein lipase-deficient mice by somatic gene transfer of the naturally occurring LPLS447X beneficial mutation. Arterioscler Thromb Vasc Biol. 2005;25(10):2143-50. 
21. Pendharkar SA, Asrani VM, Xiao AY, Yoon HD, Murphy R, Windsor JA, Petrov MS. Relationship between pancreatic hormones and glucose metabolism: A cross-sectional study in patients after acute pancreatitis. Am J Physiol Gastrointest Liver Physiol. 2016;311(1):G50-8. doi: 10.1152/ajpgi.00074.2016.

22. Yan SX, Li X, Sun CD, Chen KS. Hypoglycemic and hypolipidemic effects of quercetin and its glycosides. Zhongguo Zhong Yao Za Zhi. 2015;40(23):4560-7. PMID: 27141664.

23. Stefanutti C, Labbadia G, Morozzi C. Severe hypertriglyceridemiarelated acute pancreatitis. Ther Apher Dial. 2013;17(2):130-7. doi: 10.1111/1744-9987.12008.

24. Hofbauer B, Friess H, Weber A, Baczako K, Kisling P, Schilling M, Uhl W, Dervenis C, Büchler MW. Hyperlipaemia intensifies the course of acute oedematous and acute necrotising pancreatitis in the rat. Gut. 1996;38(5):753-8. PMID: 8707124.

25. An F, Zhan Q, Xia M, Jiang L, Lu G, Huang M, Guo J, Liu S. From moderately severe to severe hypertriglyceridemia induced acute pancreatitis: circulating miRNAs play role as potential biomarkers. PLoS One. 2014;9(11):e111058. doi: 10.1371/journal. pone.0111058.

\section{Correspondence:}

Yan Zhao

Department of Gastroenterology

Shanghai Tenth People's Hospital, Tongji University School of Medicine No. 301 Yanchangzhong Road

Shanghai 200072 China

yanzhaocn@yeah.net

Received: Jun 06, 2016

Review: Aug 09, 2016

Accepted: Sep 12, 2016

Conflict of interest: none

Financial source: National Natural Science Foundation of China $\left(\mathrm{N}^{\circ}\right.$ 81570578)

${ }^{1}$ Research performed at Department of Gastroenterology, Shanghai Tenth People's Hospital, Tongji University School of Medicine, Shanghai, China. 